\title{
Anglicisms as Neologisms in the Albanian Press from the 1990s
}

\author{
Irena Pata Kapo \\ University of Tirana, Faculty of Foreign Languages, \\ Department of English Language, Tirana, Albania \\ irenakapo@yahoo.com, irenapata@gmail.com
}

\author{
Doi:10.5901/jesr.2016.v6n1p141
}

\begin{abstract}
The influence of the English language on the Albanian language, a phenomenon of the last two decades, seems to be drawing the linguists' attention. A corpus of 511 Anglicisms bears witness to the active life of these English borrowings in the Albanian press after the 1990s. This paper outlines some aspects of Anglicisms' life and 'behaviour' in Albanian press language. It deals with some aspects of their morpho-syntactic, phonetic, orthographic and semantic analysis. It also draws a distinction between Anglicisms that have been subjected to the grammatical rules of the Albanian language and those that have entered Albanian keeping their English language properties intact. Anglicisms as neologisms shall be the focus of this modest contribution in this vase area of study and research. A generally positive attitude is held towards the use of Anglicisms in the Albanian press language in order to fill the lexical gaps with words and phrases denoting new concepts and notions or carrying extra connotative meanings rather than their use to duplicate existing lexical units in Albanian, in an effort to preserve the Albanian language identity in this globalization epoch of ours, thus contributing to the linguistic and cultural heritage of the country.
\end{abstract}

Keywords: English borrowings, Anglicisms, pseudoanglicisms, neologisms, morphological/phonetic/orthographic/syntactic adaptation

\section{Introduction}

It is widely accepted that there is a flux of English words in Albanian language and particularly in the written press language since the 1990 - the time when the Albanian society and media became free from the communism chains. Their frequent use is verified in all types of media, audio and visual ones, but also in the everyday language of the young and middle generation in particular. This paper contains many examples taken from the Albanian daily press from the 1990 and on and have been the object of a long term research on the features and behaviour of Anglicisms in the Albanian written press.

One of the most complicated issues related to Anglicisms in Albanian is their identification. Anglicisms refer to the borrowings from English language which come to adapt to the target language, with the purpose to be integrated to its linguistic system.

There are cases when Anlicisms in the press are used to express a word recently adopted in Albanian language, often due to its shortness in comparison to the Albanian counterpart word, as it is the case with the word census which in Albanian has a longer and well established version, 'regjistrim i popullsisë':

Anketuesit mbërrijnë në dyert e shqiptarëve, starton censusi (Shqip newspaper, 2.10.2011, pg. 4)

There are also many other cases in which Anglicism are used extensively although in Albanian already exists a word/translation for that, replacing the Albanian word in many contexts: workshop and seminar. The reason beyond that lies in the tendency of the speakers to sound -'more modern' in their talk:

Përveç kompeticionit do të ketë edhe workshope (Klan magazine, 7.12.2007, pg. 62)

In other cases Anglicisms are completely adapted to the Albanian graphics and pronounciation of the Albanian language, as it is the case with menaxher:

Megjithatë duket se Jasson, i cili është dhe menaxher i saj, nuk e pëlqen idenë e martesës ('Koha jonë' newspaper, 7.8.2009, pg. 14)

While in the other countries of Europe, the study on Anglicisms and their features and behaviour in different European languages dates back since the middle of the twentieth century (with highly recognized researchers and linguists as Rudolf Filipovic, Manfred Görlach with his Dictionary of European Anglicisms, Ivan Klajn, etc., in Albania this is rather a new phenomenon; whereas studies from the Kosovo researchers and linguists date a lot earlier and are more concrete with names like Vesel Nuhiu, Ismail Mehmeti etc. 
In the Dictionary of European Anglicisms, Manfred Görlach includes Albanian language as one of the 16 European languages, whose Anglicisms he has collected. Görlach also refers to the lack of studies in this particular area of linguistics particularly in Albania. The research studies of two Kosovo linguists, that date back to 1980s, have been the source of the data for Görlach and his dictionary, thus without any concrete contribution from the Albanian language institutions of Tirana.

One of the primary conditions for two languages to exhange lexical items between each other is the geographical proximity, but this is not the case with the two languages in question, Albanian and English language, i.e. referring to the countries where they are basically spoken. If we refer to the history of the written Albanian language, English words have been borrowed in Albanian since its first publications, starting from the middle of XIX century and on. These publications include school texts as well as newspapers published in the two languages such as Dielli, Laboremus etc. Two other factors that promoted further the borowings from English were the opening of the Albanian-American Institute of Kavaja and the establishing of the American "Harry Fultz" High School in 1925.

In the XX century, after the turmoil the two World Wars brought in the region, and in Albania, in comparison to other countries Albania somehow lost contact with English language and culture due to the communist regime established in this country as soon as the war came to an end. Regardless the isolation, English language continued to be a priority and the first foreign language taught in most of the Albanian schools, and Albanian society had a very positive orientation towards English language and culture, even though hidden and covered from the fear of the different forms of punishment established by the regime, and being more oriented towards English culture, cinema, music, movies and sports originating from the English speaking countries.

After the 1990 (the year that marked the change of the systems in Albania), the Euro-atlantic integration of the country became the real issue for our country and as a result the contacts and relations with many international organisms (OSCE, Council of Europe, NATO, etc.) increased, bringing to another development stage the English borrowings in Albanian language. The opening of the borders was not only literal but released the borders of Albanian culture, politics, media, etc., to have a free exchange with the 'other world' and particularly the global language, English language. English language still continues to be a priority in the Albanian education and is one of the main conditions to be met for providing a job position.

\section{Main Text}

Many of the English words used in Albanian language, in the written and spoken language, very often are used not only for necessity. The language of the media has shared many elements with other types of discourse. In order to fulfill the mission of the press (among others to prepare and disseminate the news in a short time and in a limited space as effectively as possible), it has become of use the high number of borrowings, especially those from English language. They are used as synonyms of the words already existing in Albanian, for euphemisms, etc.. Some of them are used temporarily and disappear after a short period of time. It seems like they serve only to the news they introduce, and disappear together with the 'rumour' it brings about, and in the future are identified with this news. Such examples include impeachment, exit poll, dance off etc. Many of the newspaper readers or the TV audience would not be aware of the existence of such phrases as "dance off' ( Nga ana tjetër, Bigut i takonte të festonte dyfish, pasi ai i shpëtoi "dance off-it", ku triumfoi ndaj francezes Eloise le Petit. (Panorma newspaper, 14.5.2011, pg. 27), "show down" or "sing off' if they didn't become fans of the famous TV shows such as "Dancing with the stars" or "X-Factor".

A considerable number of English borrowings are used as a need, introducing in Albanian new concepts and new terms, enriching terminology of different areas. These terms often are not translated because of the speed with which the news is aimed to be provided (abstrakt, badminton, banner, by-pass, gigabajt etc). The foreign words hit the reader by connoting a meaning in the textual level. English borrowings do not have only a denotative function, but it is important the fact that they can be used together with the Albanian words, serving to different contexts with their connotative values (big, house, bomber, target, jackpot, raund etc). They have a considerable emotional value with which the journalists can give also an individual message. This explains also the stylistic weight the words like killer or lider have in comparison with their equivalents in Albanian vrasës and udhëheqës.

From the classification of the glossary words $80.4 \%$ of the Anglicisms mark a new concept in Albanian language, whereas $3.9 \%$ have connotative values, and $10.9 \%$ have connotative and denotative values.

In writing about neologisms in Albanian language in relation to the English loans we cannot but include also the category of the so called 'pseudoanglicisms' - 'false loans' or'words that look like English due to their English components in them but that do not really exist in English language'. Pseudoamglicisms include the short forms or the 
compositions, that are used to denote the whole composition. Some linguists believe that when these words are shortened or simplified, thus one of the constituent elements drops, the words fall into the category of pseudoanglicisms or pseudo-loans (N. Alexieva, "How and why are Anglicisms often lexically different from their English etymons?", Anglicisms in Europe, Cambridge Scholars Publishing, 2008, pg. 46): night is used to refer to the night-club, parking instead of parking lot etc. 'The clipped loans' occur in most of the European languages; according to the Dictionary of European Anglicisms of Görlach the word 'parking', for example occurs in 12 from 16 languages included in this dictionary, 'kamping' in 15 European languages (instead of 'camping site'), 'holding' in 9 languages, etc.

Another category of 'pseudoamglicisms' are the loans deriving from other languages in contact such as Italian and French. However, it is difficult to define the exact limit between the English words originating directly from English language and those originating from other languages. Also Görlach, in his Dictionary of European Anglicisms identifies many Anglicisms in Albanian originating from other languages like French, Italian, Russian, etc.. For instance, he considers action as an Anglicism originating in Albanian from French language (Görlach, 2001, pg. 2), apartament from French language (Görlach, 2001, pg. 7), barelë from Italian language (Görlach, 2001, pg. 16), biftek (Görlach, 2001, pg. 20) from French, kamp (Görlach, 2001, pg. 46) from French, karton (Görlach, 2001, pg. 50) from Italian, kampion (Görlach, 2001, pg. 50) from Italian, shans (Görlach, 2001, pg. 55) from French, krem (Görlach, 2001, pg. 77) from French, ese (Görlach, 2001, pg. 106) from French, profesional (Görlach, 2001, pg. 243) from Italian, etc.

Another feature of Anglicisms as neologisms in Albanian language is their uncertainty regarding pronounciation. Their changing phonetical form speaks about the stage of Anglicisms still being unadapted in Albanian, or at least not having acquired a final form in the target language. The following Anglicism is an example in this context. Under the influence of Italian language and press the English word has acquired a pronounciation and spelling reflecting different influences from one sentence to another.

Në sitin e Ministrisë së Turizmit janë hedhur disa të dhëna... (Klan magazine, No. 541, pg. 27)

Edhe në Internet kanë lulëzuar site të cilat i drejtohen grave... (Klan magazine, 21.7.1998, pg. 54)

... dhe pas një proçesi përpunimi të materialeve, për të verifikuar autenticitetin, ato publikohen në sajt. (Klan magazine, 7.8.2010, pg. 5).

Fjala është për Altin Haxhin i cili nënshkroi një kontratë me Anorthis, një lajm që jepet edhe nga sajti i klubit qipriot. (Albania newspaper, 26.6.2005, pg. 23).

Dikur as që mendohej të gjendej një informacion on-line, ndërsa sot çdo njësi në zonat urbane ka sajtin e saj. (Albania newspaper, 23.8.2007, pg. 22).

Në sitin zyrtar të grupit nuk figuron asnjë koncert në vendin tonë. ('Koha jonë' newspaper, 11.8.2009, pg. 15).

Disa nga sajtet amerikane online e kanë tallur dhe vënë në shënjestër Obamën. ('Shekulli' newspaper, 16.8.2010, pg. 20).

Another interesting category of Anglicisms that are neologisms in Albanian are the pseudoanglicisms that are proper nouns or the well-known English-American trademarks used as common nouns not only in Albanian but also in other language, such as Gillette or pampers, coming from the recognized trademark for producing diapers but that in Albanian is generalized being used only to the diapers and not at all to the specific trademark.

In this group are also included the neologisms that are formed with English elements, but that do not represent real English words in themselves, e.g. those with the suffix _man. In general, these pseudoanglicisms have derived from the need to name the author/doer etc., of some action: rekord - rekordmen (referring to record holder), or the newly invented Albanian word with English elements but that do not exist in English language: bllokmen, referring to the communist leaders living in a decent and beautiful area near the center of Tirana.

It cannot but be considered a neologism the English words used in Albanian language but in a different grammatical category, one that the word does not recognize in the source language. Except being neologisms, they also fall in the category of pseudoanglicisms in Albanian. For example the adjective snob, which in Albanian is also used as a verb, 'snoboj' - acquiring an Albanian verb suffix, while this category is non-existent in English language for this specific word:

Peqinasit 'snobojnë'kupën, presin merkaton e dimrit ('Panorama Sport' newspaper, 13.12.2012, pg. 6).

Or the adjective soft in English language, in Albanian is used with another meaning in the computer technology domain: 'computer program', as a short form for sofwear, and being used as a noun:

Softi tjetër që do ndërtohet për noterët për Tiranën e Durrësin është 300 mijë euro dhe kjo është parashikuar në buxhetin e 2012 ('Shekulli' neswpaper, 8.12.2011, pg. 5);

Regarding the phonetical behaviour of the neologisms with an English origin in Albanian, it can be said that a phonetical compromise has been achieved as in many other languages (Filipović, 1958, pg. 77), thus, a product that 
carries pronounciation elements from the two languages, but in most of the cases is easily distinguished as a loan.

Since the beginning of the 1990s English words have experienced changes not only in their spelling but also in their pronunciation: the Albanian speakers sometimes have the tendency to imitate the English sounds, while for as much as it appears difficult for the non-speakers of English language, they tend to eliminate the last sound of specific words or to completely modify them. For instance the name of one of the most known TV channels in Albania - 'Top Channel': some category of people would pronounce it /topt]ena / instead of /top tJenəl// /kopjutə:/ instead of /kompjutə:/, hitparade was pronounced /iparej/ rather than /hit pəreid/, etc. For certain categories of people there was a difficulty pronouncing also the word - manager - making its pronounciation an object of the humor shows in Albania: /mantandzer/ instead of /mænidzər/ etc.

Thus, being not guided by proper instructions on how to pronounce these neologisms in Albanian brings about a confusing situation in the media but also among common people. They are mainly based on their occasional hearing perception and not on the education and media guidance.

In the context of their morphological adaptation, the collected corpus of Anglicisms consists in 511 Anglicisms, out of which $87.6 \%$ are nouns, about $12.7 \%$ adjectives, $4.1 \%$ verbs, $0.9 \%$ adverbs and $1.5 \%$ noun phrases.

Another interesting observation is related to the gender of Anglicisms in Albanian language. In general they fully adapt to the gender system of Albanian but still some of the neologisms from English language whose lexical meaning is masculine, in Albanian can be used in masculine and feminine as long as a feminine suffix is added to them. As a result there is a contradiction between the lexical meaning and the morphological category indicator:

biznesmen - biznesmene, barmen - barmene, kaubojs - kaubojse, kongresmen - kongresmene, narkoman narkomane, supermen - supermene, xhentëllmen - xhentëllmene.

A different form of plurality is recognized in Albanian as a result of the English words impact. The neologisms in this category carry the plurality indicator of English nouns and the plurality indicator of Albanian nouns: (one)

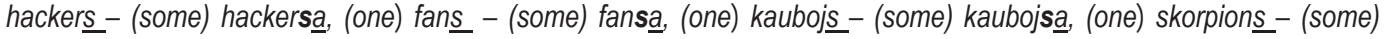
skorpionsa etc.

There is a category of neologisms in Albanian language that are formed as a result of the semantic extension of the Anglicisms. These loans in Albanian language have acquired an extra meaning or a meaning that is completely different from the meaning they have in the source language:

FITNESS - Engl.: "the state of being physically healthy and strong", in Albanian this word refers to the whole phrase 'fitness center'

EXCHANGE - Engl. "the process of changing an amount of one currency (= the money used in one country) for an equal value of another", in Albanian is used meaning 'currency exchange location/office etc.' etc.

A sub-category of this group includes those words part of the Albanian lexis but that under the influence of English language have acquired an extra meaning:

ABSTRAKT - (adj.) In the dictionary of Albanian language the meaning of this word is "not concrete", whereas under the influence of English it has acquired another meaning in Albanian: (noun) "a short piece of writing containing the main ideas in a document"

ANEKS - in the dictionary of Albanian language: "an extra part in a room, apartment, etc", the Anglicism meaning: "an extra section of a document"

AUDIENCE - in the dictionary of Albanian language: "an official reception ceremony...", the Anglicism: "the group of people who have gathered to watch or listen something"

EKSPERTIZË - in the dictionary of Albanian language (medicin) "an investigation or analysis provided by the medical expert", the Anglicism: "expert knowledge or skill in a particular subject"

EKSTRAKT - in the dictionary of Albanian language (chemistry) "the matter exctracted from the plants, animals, etc through the chemical, physichs processes", the Anglicism: "a short passage from a book, etc.".

METAL - in the dictionary of Albanian language: "chem. A type of solid mineral substance...", the Anglicism: "(music) heavy metal"

SPIKER - in the Albanian dictionary: "a person who gives a talk or a speech", Angl. "the title of the person whose job is to control the discussion in parliament"

STATUS - in the Albanian dictionary: "a legal, social position etc., of someone or something in relation to others", the Anglicism: "the situation at a particular time during a process (such as facebook, twitter etj."

Në faqen personale në Facebook ai postoi statuse të ndryshme, ku shprehte adhurim për këtë kafshë inteligjente. (Shqip newspaper, No. 106, pg. 22). 


\section{Conclusions}

- It is more than two decades now that the flux of Anglicisms is recognised as an important point of discussion also in Albanian language and for the Albanian linguists.

- There are several reasons why many Albanians nowadays prefer to use English originated neologisms. They derive from the need to fill the lexical gaps of our language, to saving space and time preferring the short version Anglicisms suggest rather than longer words in Albanian, to the modern choice of words identifying themselves with the distinct English language and the developed respective country.

- Albania still lacks proper studies in the area and there are some years that the need to regulate the positioning of Anglicisms has arised, with the increasing and even more intense contacts the two languages are experiencing.

- Neologisms deriving from Anglicisms in Albanian may arise and disappear together with the news that makes them part.

- In many areas like computer science, economics, gastrology, cinematography, sport, music etc., Anglicisms are the most needed and used neologisms.

- A considerable number of neologisms deriving from Anglicisms in Albanian have their equivalent in Albanian. Still the speakers prefer to use the English version out of the higly connotative value these words carry.

- Various pseudo-anglicisms categories are a very important part of neologisms of an English origin, starting from the clipped loans, to the invention of new words in Albanian, that contain English elements or that have an English pronunciation or spelling. Here are also included pseudo-anglicisms that derive from other languages with whom Albanian has been and is still in contact.

- One of the features these neologisms have currently has to do with the unstable spelling, pronunciation and different forms of adaptation they have due to the very caotic situation that exists nowadays with Albanian language rules and users.

- A very interesting category of English originating neologisms are the new words created in Albanian of a different grammatical category of the Anglicisms in question, compared to the counterpart category in the source language.

- Being adapted in the gender and plurality system of Albanian language there is another category of neologisms formed out of the Albanian language gender and plurality indicators, although in several times they are in contradiction with their lexical meaning.

- The last category of neologisms introduced in this paper is related to the newly created words, to whom a completely different meaning is granted in Albanian; or other extra meanings acquired by words included in the Albanian language dictionary.

\section{References}

Cipo Kristaq, 2003, Phonetics, Akademia e Shkencave e Shqipërisë, Instituti i Gjuhësisë dhe i Letërsisë, Tirana

Dhrimo Ali, Memushaj Rami, 2011, Albanian Language Dictionary, Infobotues

Filipović Rudolf, 1968, Semantic Extension Changes in Adaptation of English Loan-Words in Serbo-Croation, Studia Romanica et Anglica, Zagrebiensia

Filipović Rudolf, 1961, The Morphological Adaptation of English Loan-Words in Serbo-Croat, Studia Romanica et anglica, Zagrabiensia

Filipović Rudolf, 1982, The English Element in European Languages, Zagreb

Filipović Rudolf, 29.9.2006, English as a word donor to other languages of Europe, http://uww.intellectbooks.com/europa/number5/hart.htm Filipović Rudolf, 1958, The phonetic Compromise, Studia Romanica et Anglica, Facultas Philosophica Universitatis Studiorum, Zagreb

Fischer R., Pulaczewska H., 2008, Anglicisms in Europe: Linguistic Diversity in the Global Context, Cambridge Scholars Publishing Orthography Dictionary of the Academy of Sciences of Albania, 1976

Fowler R., Language in the News, Routledge, 1991, London

Görlach Manfred, 2002, English in Europe, Oxford University Press

Görlach Manfred, 2001, A Dictionary of European Anglicisms, Oxford University Press

Hornby A.S., 1989, Oxford Advanced Learner's Dictionary, Oxford University Press

Jorgaqi K., 1998, On the lexical-semantic integration of the Italianisms in the standard Albanian language, Studime Filologjike, Akademia e Shkencave e Republikës së Shqipërisë, Instituti i Gjuhësisë dhe i Letërsisë, 1-2,

Kapo Irena, 2013, PhD thesis: On the impact of English language on the post-communist press in Albania' 
Kapo Irena, 2006, Master degree microthesis: 'Features of the media language[

Klajn I., 1972, Influssi Inglesi nella lingua italiana, Firence, Olschki

Kërçira Rajmonda, 2005, Anglicisms in Albanian: A Direct and Mediated Language Contact Phenomenon, Graz, Instituti i Anglistikës

Lafe Emil, 2004, Language of the media - problems and tasks, Gjuha jonë

Lloshi Xhevat, 2001, Stylistics of the Albanian language and Pragmatics, Shtëpia Botuese e Librit Universitar

Lloshi Xhevat, 2005, Albanian language facing globalization trends, Studia Albanica, Akademia e Shkencave të Shqipërisë

Lloshi Xhevat, 2011, English loans examples in Albanian', Studime filologjike, no. 1-2, pg. 68-75

Për pastërtinë e gjuhës shqipe (Dictionary), 1998, Akademia e Shkencave të Shqipërisë

Shehu Hajri, 2002, About Anglicisms in the Current Media, Studime Filologjike, 3-4, Akademia e Shkencave e Shqipërisë, Instituti i Gjuhësisë dhe i Letërsisë

Shkurtaj Gjovalin, 2004, Writing and Pronounciation in the Current media, Gjuha jonë

Topalli Kolec, 2007, Phonetics of Albanian language, Akademia e Shkencave e Shqipërisë, Instituti i Gjuhësisë e Letërsisë, DITURIA 